\title{
The regulatory role of cystatin C in autophagy and neurodegeneration
}

\author{
T.A. Korolenko ${ }^{1}$ @, A.B. Shintyapina ${ }^{2}$, A.B. Pupyshev ${ }^{1}$, A.A. Akopyan ${ }^{1}$, G.S. Russkikh ${ }^{3}$, M.A. Dikovskaya ${ }^{1,6}$, V.A. Vavilin ${ }^{2,5}$ \\ E.L. Zavjalov ${ }^{5}$, M.A. Tikhonova ${ }^{1,4}$, T.G. Amstislavskaya ${ }^{1,4}$ \\ ${ }^{1}$ Scientific Research Institute of Physiology and Basic Medicine, Novosibirsk, Russia \\ ${ }^{2}$ Scientific Research Institute of Molecular Biology and Biophysics, Federal Research Center for Basic and Translational Medicine, Novosibirsk, Russia \\ ${ }^{3}$ Scientific Research Institute of Biochemistry, Federal Research Center for Basic and Translational Medicine, Novosibirsk, Russia \\ ${ }^{4}$ Novosibirsk State University, Novosibirsk, Russia \\ ${ }^{5}$ Institute of Cytology and Genetics, SB RAS, Novosibirsk, Russia \\ ${ }^{6}$ S.N. Fedorov NMRC "MNTK "Eye Microsurgery", Novosibirsk Branch, Novosibirsk, Russia \\ 凶e-mail: t.a.korolenko@physiol.ru
}

Autophagy is a dynamic cellular process involved in the turnover of proteins, protein complexes, and organelles through lysosomal degradation. It is particularly important in neurons, which do not have a proliferative option for cellular repair. Autophagy has been shown to be suppressed in the striatum of a transgenic mouse model of Parkinson's disease. Cystatin $\mathrm{C}$ is one of the potent regulators of autophagy. Changes in the expression and secretion of cystatin $\mathrm{C}$ in the brain have been shown in amyotrophic lateral sclerosis, Alzheimer's and Parkinson's diseases, and in some animal models of neurodegeneration, thus proving a protective function of cystatin $C$. It has been suggested that cystatin C plays the primary role in amyloidogenesis and shows promise as a therapeutic agent for neurodegenerative diseases (Alzheimer's and Parkinson's diseases). Cystatin C colocalizes with the amyloid $\beta$-protein in the brain during Alzheimer's disease. Controlled expression of a cystatin $C$ peptide has been proposed as a new approach to therapy for Alzheimer's disease. In Parkinson's disease, serum cystatin C levels can predict disease severity and cognitive dysfunction, although the exact involvement of cystatin $C$ remains unclear. The aim: to study the role of cystatin $C$ in neurodegeneration and evaluate the results in relation to the mechanism of autophagy. In our study on humans, a higher concentration of cystatin $\mathrm{C}$ was noted in cerebrospinal fluid than in serum; much lower concentrations were observed in other biological fluids (intraocular fluid, bile, and sweat). In elderly persons (61-80 years old compared to practically healthy people at 40-60 years of age), we revealed increased cystatin C levels both in serum and intraocular fluid. In an experiment on $\mathrm{C} 57 \mathrm{BI} / 6 \mathrm{~J}$ mice, cystatin $\mathrm{C}$ concentration was significantly higher in brain tissue than in the liver and spleen: an indication of an important function of this cysteine protease inhibitor in the brain. Using a transgenic mouse model of Parkinson's disease (5 months old), we demonstrated a significant increase in osmotic susceptibility of brain lysosomes, depending on autophagy, while in a murine model of Alzheimer's disease, this parameter did not differ from that in the appropriate control.

Key words: cystatin C; autophagy; neurodegeneration.

For citation: Korolenko T.A., Shintyapina A.B., Pupyshev A.B., Akopyan A.A., Russkikh G.S., Dikovskaya M.A., Vavilin V.A., Zavjalov E.L., Tikhonova M.A., Amstislavskaya T.G. The regulatory role of cystatin C in autophagy and neurodegeneration. Vavilovskii Zhurnal Genetiki i Selektsii =Vavilov Journal of Genetics and Breeding. 2019;23(4): 390-397. DOI 10.18699/VJ19.507

\section{Регуляторная роль цистатина С в аутофагии и нейродегенерации}

Т.А. Короленко ${ }^{1}$, А.Б. Шинтяпина ${ }^{2}$, А.Б. Пупышев ${ }^{1}$, А.А. Акопян ${ }^{1}$, Г.С. Русских ${ }^{3}$, М.А. Аиковская ${ }^{1,6}$, В.А. Вавилин ${ }^{2,5}$, Е.А. Завья ов $^{5}$, М.А. Тихонова ${ }^{1,4}$, Т.Г. Амстиславская ${ }^{1,4}$

\footnotetext{
${ }_{1}^{1}$ Научно-исследовательский институт физиологии и фундаментальной медицины, Новосибирск, Россия

${ }^{2}$ Научно-исследовательский институт молекулярной биологии и биофизики, Федеральный исследовательский центр фундаментальной и трансляционной медицины, Новосибирск, Россия

${ }^{3}$ Научно-исследовательский институт биохимии, Федеральный исследовательский центр фундаментальной и трансляционной медицины, Новосибирск, Россия

${ }^{4}$ Новосибирский национальный исследовательский государственный университет, Новосибирск, Россия

5 Федеральный исследовательский центр Институт цитологии и генетики Сибирского отделения Российской академии наук, Новосибирск, Россия

${ }^{6}$ НМИЦ «МНТК «Микрохирургия глаза им. акад. С.Н. Федорова», Новосибирское отделение, Новосибирск, Россия

凶e-mail: t.a.korolenko@physiol.ru
}

Аутофагия - динамичный клеточный процесс, связанный с оборотом белков, белковых комплексов и органелл посредством лизосомной деградации. Аутофагия особенно важна в нейронах, которые не имеют пролиферативного ресурса для клеточного восстановления. Одним из мощных регуляторов аутофагии является цистатин С. Изменения экспрессии и секреции цистатина С в головном мозге показаны при боковом амиотрофическом склерозе, болезни Альцгеймера и Паркинсона, а также на некоторых моделях нейроде- 


\begin{abstract}
генерации у животных, что подтверждает защитную функцию цистатина С. Высказано предположение, что цистатин С играет важную роль в амилоидогенезе и может рассматриваться как возможное терапевтическое средство для предупреждения и лечения ряда нейродегенеративных заболеваний (болезни Альцгеймера и Паркинсона). Цистатин С колокализуется с амилоидом $\beta$ в головном мозге при болезни Альцгеймера. Контролируемая экспрессия пептида цистатина С предложена в качестве нового подхода к терапии болезни Альцгеймера. При болезни Паркинсона уровни цистатина С в сыворотке крови могут прогнозировать тяжесть заболевания и когнитивную дисфункцию, хотя конкретное участие цистатина С остается неясным. Рассмотрена роль цистатина С в нейродегенерации и проведена оценка результатов в связи с активностью аутофагии. У здоровых людей обнаружена высокая концентрация цистатина С в спинномозговой жидкости по сравнению с сывороткой крови; значительно более низкие концентрации наблюдали в других биологических жидкостях (внутриглазная жидкость, желчь, пот). При оценке влияния возраста обнаружено повышение концентрации цистатина С как в сыворотке, так и во внутриглазной жидкости у пожилых людей (61-80 лет) по сравнению с практически здоровыми людьми в возрасте 40-60 лет. В эксперименте на мышах C57BI/6J концентрация цистатина С была значительно выше в мозговой ткани, чем в печени и селезенке, что указывает на важную функцию этого ингибитора цистеиновых протеаз в головном мозге. На трансгенной мышиной модели болезни Паркинсона (5 месяцев) найдено значительное увеличение осмотической чувствительности лизосом мозга, соответствующее усилению аутофагии, тогда как на мышиной модели болезни Альцгеймера этот показатель не обнаружил изменения аутофагии.

Ключевые слова: цистатин С; аутофагия; нейродегенерация.
\end{abstract}

\section{Introduction}

The search for new markers of aging, neurodegenerative diseases, and atherosclerosis is important for modern medicine (Ciechanover, Kwon, 2015). Cystatins are known to be potent endogenous inhibitors of cysteine proteases of the papain superfamily and form equimolar, tight, and reversible complexes with human cysteine proteases (cathepsins B, H, K, L, and S) (Stoka et al., 2005; Korolenko et al., 2011, 2015).

Cystatin $\mathrm{C}$ is a known extracellular endogenous cysteine proteinase inhibitor, which has been studied more thoroughly than other cystatins (cystatin SN et al.) and has been evaluated as a possible marker of several pathological processes (tumor growth and metastasis) (Poteryaeva et al., 2000; Maxfield, 2014). Increased serum cystatin $C$ concentration is well known as an alternative measure of renal function (Keppler, 2006). According to the recent findings cystatin $\mathrm{C}$ is regulated at both transcriptional and post-translational levels (Xu et al., 2015), moreover, cystatin C production by haematopoietic cells is significant in the systematic pools of this inhibitor.

Neurodegenerative diseases combine disturbances in certain structures of brain cells (especially in endosomes and lysosomes), which, in the presence of the signs of such a disease, include some common molecular and cellular mechanisms (Harris, Rubinsztein, 2011). Protective mechanisms of action of cystatin $\mathrm{C}$ in several neurodegenerative diseases (Alzheimer's disease, Parkinson's disease) were suggested (Gauthier et al., 2011). Cystatin C was shown previously implicated in the process of neurodegeneration (Kaur, Levy, 2012). An in vivo study on dopaminergic-neuron survival revealed that administration of cystatin $\mathrm{C}$ to rats with a neurotoxin 6-hydroxydopamine-induced lesion partially rescues substantia nigra dopaminergic neurons. 6-Hydroxydopamine-mediated lesioning induces relatively slow but sustained upregulation of cystatin $\mathrm{C}$ and suggests that this inhibitor may exert a neuroprotective action on dopaminergic neurons (Xu et al., 2005). Those authors show that cysteine proteinase inhibitors may be new candidates for neuroprotective treatment of Parkinson's disease (Cuervo, Wong, 2014).

We tried to evaluate the biological role of cystatin $\mathrm{C}$ in neurodegeneration, especially as autophagy inducer, which remains unclear and controversial until now. Destruction of the nigrostriatal dopaminergic pathway can trigger neuroinflammation and increase the synthesis of neural growth factors, both in the striatum and in the substantia nigra. In general, the pathological processes involved in such responses are poorly characterized and may contribute to secondary damage and/or regeneration in the central nervous system (Ling, Salvaterra, 2009; Harris, Rubinsztein, 2011). Increased levels of p62 (also called as sequestosome 1 (SQSTM1) and higher sensitivity to 7-oxysterol-mediated lysosomal membrane damage was shown in macrophages isolated from cystatin $\mathrm{C}$ knockout $\left(\mathrm{CysC}^{---}\right)$mice (Li et al., 2016).

\section{Cystatin $C$ as a possible diagnostic marker of neurodegenerative diseases}

Cystatin $\mathrm{C}$ has a broad spectrum of biological roles, including modulation of inflammatory response (Li et al., 2016). Using immunohistochemical methods in Alzheimer's disease Zhong et al. (2013) have revealed that cystatin C co-localizes with amyloid- $\beta$ in amyloid-laden vascular walls and in the senile plaque cores. These authors suggested that cystatin $\mathrm{C}$ revealed protection against neurodegeneration by inhibition of cysteine proteases (cathepsin B), suppression of amyloid- $\beta$ aggregation and induction of autophagy (Zhong et al., 2013). Low cystatin $\mathrm{C}$ level in cerebrospinal fluid of patients with Alzheimer disease and dementia confirmed this hypothesis. In elderly men (free of dementia at the baseline) low levels of serum cystatin $\mathrm{C}$ can precede clinical manifestation of Alzheimer's disease and may be an early marker of future risk of Alzheimer's disease development (Sundelöf et al., 2008). Plasma Cys C levels were significantly correlated with dementia development in Alzheimer's disease and combination (ratio) of elevated cystatin C and decreased HDL concentrations were suggested recently as potential diagnostic value test in differential diagnosis of Alzheimer's disease and vascular dementia (Wang et al., 2017).

In the brain, Mathews and Levy (2016) have demonstrated that cystatin $\mathrm{C}$ is playing protective roles via several different pathways that depend upon the inhibition of endosomal-lysosomal proteolysis (cysteine proteases inhibition), the induction of cellular autophagy, via the induction of cell proliferation and the inhibition of amyloid- $\beta(A \beta)$ aggregation. However, 


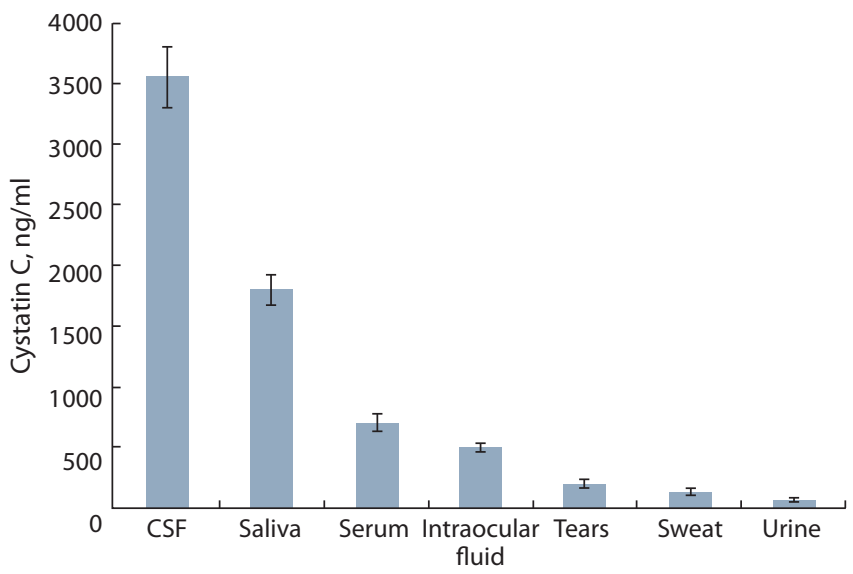

Fig. 1. Distribution of cystatin $C$ in biological fluids of healthy persons, aged 30-50 years old $(M \pm m), n=7-10$ per group.

Samples of CSF (cerebrospinal fluid) were obtained from the Federal Center for Neurosurgery, Novosibirsk, when puncturing patients for a diagnostic purpose that were considered as practically healthy individuals according to the cellular composition of CSF revealed. Cystatin C concentration was measured by Cystatin C Human ELISA kits, BioVendor (Czechia).

there are opposite points of view of researchers suggesting that brain amyloid- $\beta$ level depends mainly on a balance between its formation from the amyloid precursor protein (APP) and its removal by proteolysis, with a significant role of several zinc-proteases including neprilysin, the endothelin converting enzymes (ECE-1 and -2), and the insulin-degrading enzyme (Nalivaeva, Turner, 2017). Moreover, cathepsin B, as the most important cysteine protease, might be also anti-amyloidogenic, helping in amyloid- $\beta$ clearance or, instead, might be involved in amyloid- $\beta$ production (Zerovnik, 2009).

Parkinson's disease is characterized by a decreased motor activity resulting from the death of dopaminergic neurons in the substantia nigra. $\alpha$-synuclein, located in presynaptic terminals of neurons, is considered as the main pathogenic protein in Parkinson's disease; another strong pathogenic factor is oxidative stress (Hara et al., 2006; Huang et al., 2015). Dopamine can induce autophagic cell death with upregulation of $\alpha$-synuclein in human neuroblastoma cells (Gomez-Santos et al., 2003).

An increased serum level of secreted cystatin $\mathrm{C}$ was demonstrated during the process of aging (Cuervo, Wong, 2014; Mathews, Levy, 2016) and in various diseases like tumors (Gashenko et al., 2013) or atherosclerosis (Korolenko et al., $2011,2012,2015)$. In biological fluids of healthy persons, the highest concentration of cystatin $\mathrm{C}$ in our study was noted in cerebrospinal fluid (CSF), with the following ranking of concentrations: $\mathrm{CSF}>$ saliva $>$ serum $>$ intraocular fluid $>$ tear fluid $>$ sweat $>$ urine (Fig. 1).

Results similar to our data concerning cystatin $\mathrm{C}$ levels in CSF, saliva, and serum were obtained by other authors (Bjornstad et al., 2015). According to the data that we obtained in practically healthy persons, the concentration of cystatin $\mathrm{C}$ is increased in the serum and intraocular fluid of people aged 61-80 years (Fig. 2).

At early stage of Parkinson's disease, increased serum cystatin $\mathrm{C}$ was associated with sleep-disordered breathing problems (Xiong et al., 2018). In CSF of patients with amyo-



Fig. 2. Concentration of cystatin $\mathrm{C}(\mathrm{ng} / \mathrm{ml})$ in biological fluids of healthy persons depending from age, $n=7-10$ per group.

Data are presented as $M \pm m .{ }^{*} p<0.05$ vs. control (group of healthy 2029 years old individuals) or practically healthy persons of 41-60 years old. Cystatin C concentration was measured by Cystatin C Human ELISA kits, BioVendor (Czechia).

trophic lateral sclerosis cystatin C level was significantly decreased, there was a correlation between cystatin $\mathrm{C}$ levels and G73A polymorphism in CST3 gene encoding cystatin C (Yamamoto-Watanabe et al., 2010). In the brain of patients with Alzheimer's disease cystatin $\mathrm{C}$ revealed protective role as a strong endogenous inhibitor of cysteine proteases (cathepsin B), inducer of cellular autophagy related to amyloidbeta aggregation (one of the several pathways of protection) (Mathews, Levy, 2016).

Autophagy is a dynamic cellular process involved in the turnover of proteins, protein complexes, and organelles through lysosomal degradation (Chen, Klionsky, 2011). Autophagy is particularly important in neurons, which do not have a proliferative option for cellular repair (Lee, 2009; Son et al., 2012). Positive and some negative effects (like the "Janus-faced" role) of increased autophagy have been uncovered during development of neurodegeneration (Viscomi, D’Amelio, 2012; Wang, Hiesinger, 2012).

\section{The experimental model of neurodegenerative diseases, autophagy, and cystatin C}

A common feature of neurodegenerative diseases is the accumulation of proteins prone to aggregation and protein inclusions, which are, on the one hand, the markers of these diseases and, on the other hand, the cellular tools for combating these diseases; one of the important therapeutic targets in this process is autophagy (Ciechanover, Kwon, 2015; Torra et al., 2018). Autophagy is weakened in various ways in these diseases and decreases with ageing. The removal of the accumulating toxic proteins and structures is carried out by the mechanisms of chaperone-mediated autophagy, macroautophagy, and mitophagy during interactions with the ubiquitin-proteasome system.

Changes in autophagy are involved in the development of various age-dependent degenerative disorders such as neurodegeneration (Tizon et al., 2010b), cancer (Gammoh et al., 2016), tissue atrophy, alcohol neurointoxication (Luo, 


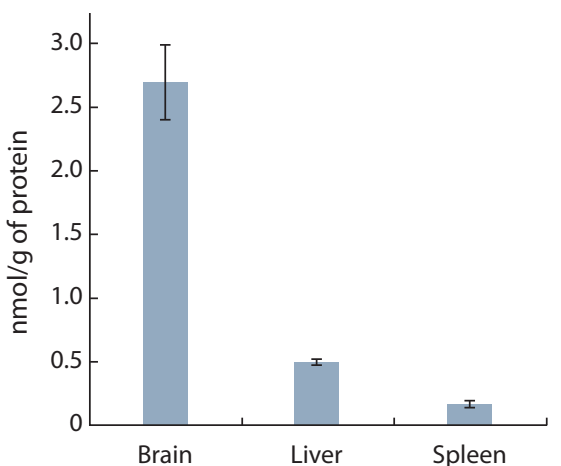

Fig. 3. Cystatin $C$ concentration in different organs in intact $\mathrm{C} 57 \mathrm{Bl} / 6 \mathrm{~J}$ mice.

Data are presented as $M \pm m, n=7$ per group. Cystatin $C$ assay was performed with ELISA kit for mice (BioVendor, Chechia).

2014) and accelerated aging (Coria et al., 1987; Kovács et al., 2017). Decreased concentration of cystatin C in CSF was reported to have diagnostic significance in neurodegenerative diseases, such as amyotrophic lateral sclerosis, which is characterized by progressive motor neuron degeneration (Mathews, Levy, 2016). Low concentration of cystatin $C$ was detected in the serum of patients with Alzheimer's disease, correlating with conversion from mild cognitive disturbances to dementia; in CSF of patients with Alzheimer's disease, the cystatin $\mathrm{C}$ level was found to be lower as compared to patients with dementia; therefore, it is possible that changes of cystatin $\mathrm{C}$ in CSF may serve as a biomarker of disease (Mathews, Levy, 2016). However, according to some data (Přikrylová Vranová et al., 2010) cystatin C level in CSF of patients with Parkinson's disease was not changed significantly.

Many studies indicate that the weakening of autophagy and/or the incompleteness of protein degradation are important initiators of Parkinson's disease (Wang, Hiesinger, 2012; Maxfield, 2014). In vitro studies have revealed that pharmacological induction of autophagy, for instance, by trehalose (Dehay et al., 2010) or by resveratrol (Wu et al., 2013), leads to an improvement in the molecular patterns of Parkinson's disease. In general, it is believed that a decrease in autophagy and in recognition of the segregated material is the key factor of Parkinson's disease, and possibly, activation of autophagy is a good therapeutic strategy against this disease.
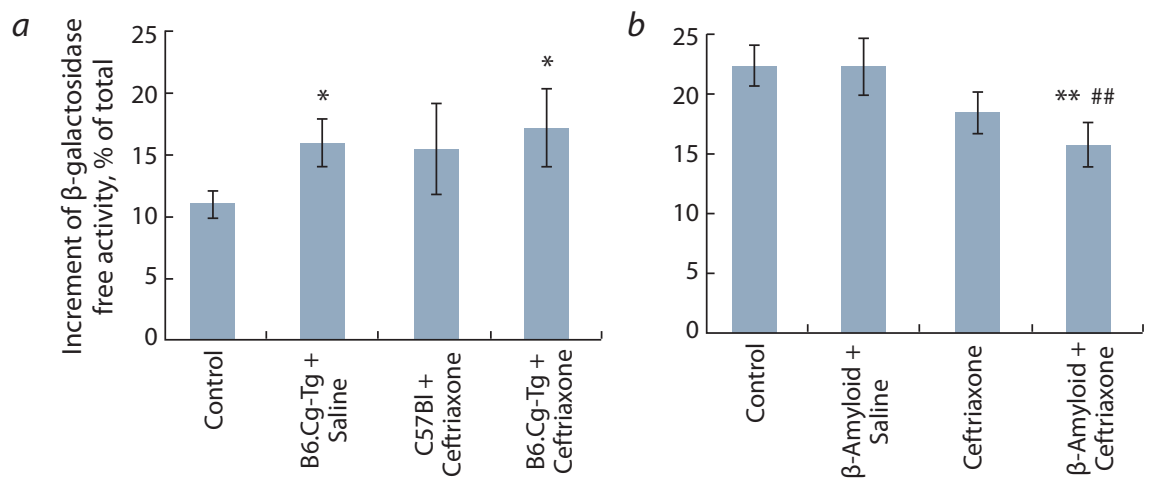

Fig. 4. Autophagy activation in the brain of murine models of Parkinson's $(a)$ and Alzheimer's $(b)$ diseases.

Data are presented as $M \pm m, n=5-6$ per group. Autophagy activation was measured by permeabilization of lysosomal membranes as an increment of free activity of $\beta$-galactosidase (in percentage of the total activity of the enzyme) after treatment of brain homogenate in hypotonic media as described in (Pupyshev et al., 2005). Ceftriaxone ( $100 \mathrm{mg} / \mathrm{kg} /$ day for 5 weeks, intraperitoneally) was applied as a neuroprotective treatment since it demonstrated a marked neuroprotective potential at experimental neurodegeneration in the models of Parkinson's and Alzheimer's disease (Weng et al., 2016; Tikhonova et al., 2017).

a, Transgenic 5-month-old mice with overexpression of a-synuclein of B6.Cg-Tg(Prnp-SNCA*A53T) 23Mkle/J strain (B6.Cg-Tg) were used as a model of Parkinson's disease (Pupyshev et al., 2018). ${ }^{*} p<0.05$ vs. Control (mice of wild-type genotype); $b$, To induce a pharmacological model of Alzheimer's disease, mice of $\mathrm{C} 57 \mathrm{BI} / 6 \mathrm{~J}$ strain were administered with an amyloid beta fragment (A 3 25-35) (Sigma) bilaterally i.c.v. as described earlier (Park et al., 2011; Choi et al., 2013). ${ }^{* *} p<0.01$ vs. Control (mice with vehicle (sterile water) i.c.v. injections); \#\# $p<0.01$ vs. $\beta$-amyloid + saline group.

Recently new pharmacological modulators of autophagy with a therapeutic potential were introduced (Galluzzi et al., 2017a, b). Among modulators of autophagy in brain cells for prevention of neurodegeneration (Cheung, Ip, 2011), various authors suggested activators of autophagy, like rapamycin (Malagelada et al., 2010), trehalose, valproate (Harris, Rubinsztein, 2011), and cystatin C (Watanabe et al., 2018).

According to our data obtained in an experimental study, the cystatin $\mathrm{C}$ level was significantly higher in the brain than in the liver or spleen of $\mathrm{C} 57 \mathrm{Bl} / 6 \mathrm{~J}$ untreated mice (Fig. 3), indicating the significant role of this inhibitor in brain tissue.

As demonstrated in our previous study on an experimental murine genetic model of Parkinson's disease, autophagy (according to LC3-II expression) was decreased in the striatum and substantia nigra as compared to other regions of the brain, thus reflecting injury of motor neurons (Pupyshev et al., 2018). This model of Parkinson's disease manifested increased osmotic susceptibility of lysosomes in the brain (according to a release of lysosomal enzyme $\beta$-galactosidase) (Fig. 4, $a$ ) in conjunction with secondary changes of their membranes as a result of dysfunction of lysosomes and intralysosomal accumulation of toxic material. In a model of Alzheimer's disease, we did not notice the changes in the permeabilization of lysosomal membranes in brain tissue (Fig. 4, $b$ ).

Stabilization of lysosomal membrane by a neuroprotector ceftriaxone (see Fig. 4, $b$ ) can be related to anti-inflammatory effect of this drug. In the pharmacological model of Alzheimer's disease caused by the central administration of amyloid $\beta$ in mice, amyloid $\beta$ toxicity produced an almost 3 -fold increase in LC3-II expression (as result of activation of autophagy related to neuroinflammatory process in the frontal cortex) (Fig. 5), and ceftriaxone significantly reduced the rate of autophagy, which apparently reflects the anti-inflammatory effect of ceftriaxone on the cerebral cortex and thereby weakening the autophagic response.

Regulation of autophagy is a comlex process, depending on the cell types and diseases, including neurodegeneration (Kiriyama, Nochi, 2015; Zou et al., 2017). Current state of knowledge concerning transcriptional, post-transcriptional, and post-translational regulation of autophagy in yeast and mammals were discussed (Feng et al., 2015; Hwang et al., 2017). Novel pharmacological modulators of autophagy were revealed under recent investigations (Ha, Kim, 2016; Gao et al., 2017; Johnston et al., 2017). Several other approaches have been suggested for restoration of autophagy (Martini-Stoica et al., 2016). One of them is introduction of 


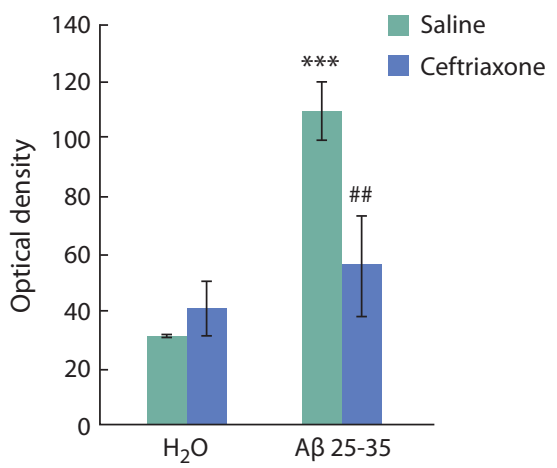

Fig. 5. Effect of ceftriaxone on LC3-II expression in the frontal cortex of $\mathrm{C} 57 \mathrm{BI} / 6 \mathrm{~J}$ mice with pharmacological model of Alzheimer's disease.

Data are presented as $M \pm m, n=3-5$ per group. Autophagy activation was measured using immunohistochemical analysis of LC3-II expression as described in (Pupyshev et al., 2018). ${ }^{* * *} p<0.001$ vs. control group $\left(\mathrm{H}_{2} \mathrm{O}+\right.$ saline $)$ of mice treated with vehicle (sterile water, i.c.v.) and intraperitoneal saline injections; $\# \#<0.01$ vs. $\beta$-amyloid+ saline group.

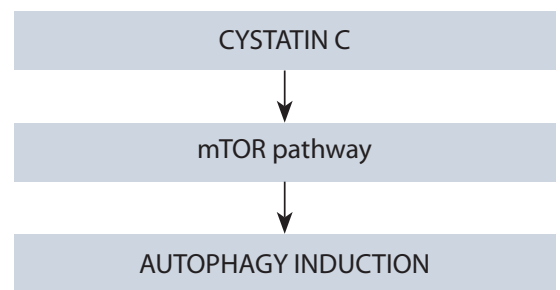

Fig. 6. Possible mechanism of regulation of autophagy in murine primary cortical neurons. The mammalian target of rapamycin (mTOR) regulates cell proliferation, cell motility, cell survival, autophagy (Tizon et al., 2010b; Zou et al., 2017).

AUTEN-99 (autophagy enhancer 99), which activates autophagy in cultured cells and animal models (Kovács et al., 2017). AUTEN-99 possibly can effectively penetrate the blood-brain barrier and somehow protect the progression of neurodegenerative changes in the experiment. Nonetheless, further research is necessary in this direction, especially a study on in vivo models of neurodegeneration.

Cystatin $\mathrm{C}$ produced by all nucleated cells and has a stable production rate; it is freely filtered by the glomerulus and metabolized after tubular reabsorption (Svechnikova et al., 1998; Bjornstad et al., 2015). Earlier cystatin C knockout mice were found to be fertile and have no gross pathological abnormality or signs of neurodegeneration up to 6 months of age (Huh et al., 1999). The absence of neurodegeneration in that study might be attributed to young age of mice (less than 6 m.o.) and strong compensatory mechanisms. Later cystatin $\mathrm{C}$ was shown to inhibit amyloid-beta deposition in Alzheimer's disease mouse models (Mi et al., 2007). Moreover, induction of autophagy by cystatin $\mathrm{C}$ may be a mechanism that protects murine primary cortical neurons and neuronal cell lines (Lee et al., 2007; Maetzler et al., 2010; Tizon et al., 2010a). In the brain, multiple in vitro and in vivo findings have demonstrated cystatin $\mathrm{C}$ protective roles via pathways that depend upon the inhibition of endosomal-lysosomal pathway cysteine proteases (cathepsin B), via the induction of cellular autophagy, via the induction of cell proliferation, or via the inhibition of amyloid- $\beta$ (A $\beta$ ) aggregation (Gauthier, Liu, 2016; Mathews, Levy, 2016).

There are some controversial results on the effect of certain drugs on serum cystatin C concentrations in humans for estimation of glomerular filtration rate (GFR) in patients with renal disease. Corticosteroids (prednisolone, repeated administration) can significantly increase serum cystatin $\mathrm{C}$ concentration from $1.24 \pm 0.40 \mathrm{mg} / \mathrm{L}$ at baseline to $1.61 \pm 0.80 \mathrm{mg} / \mathrm{L}$ at the end of a study period $(p<0.05)$. This finding needs to be considered when interpreting cystatin $C$ levels in patients with heart failure receiving corticosteroid therapy (Zhai et al., 2016).

An additional property of cystatin $C$ (except as a protease inhibitor) that makes this protein clinically relevant is that it can form aggregates by the mechanism known as domain swapping, similar to that involved in the formation of amyloid $\beta$ plaques in Alzheimer's disease (Xu et al., 2011; Kaminskyy, Zhivotovsky, 2012). Secretion of IL-10 in response to inflammatory stimuli downregulates IRF-8 and consequently cystatin $\mathrm{C}$ synthesis in vivo. The serum concentration of cystatin $\mathrm{C}$ decreases in an IL-10-dependent manner in mice treated with the TLR9 agonist CpG (synthetic analog of bacterial DNA, activator of dendrite cells). Cystatin C synthesis is therefore more tightly regulated than hitherto recognized. The mechanisms underlying this regulation may be targeted to alter cystatin $\mathrm{C}$ production, with potential therapeutic benefits (Xu et al., 2005, 2011). Transcription factor - IFN regulatory factor 8 (IRF-8) is critical for cystatin C expression in primary dendritic cells. Only the cells with IRF-8 bound to the CST3 gene promoter express high levels of this inhibitor abundantly. Cystatin $C$ can prevent formation of amyloid $\beta$ plaques associated with Alzheimer's disease and can itself form toxic aggregates. Cystatin $\mathrm{C}$ regulates NO secretion by macrophages and is a TGF- $\beta$ antagonist.

\section{New approaches to Parkinson's disease treatment}

According to data obtained by Chen et al. (2015), Hu et al. (2016), changes in the expression of cystatin C in Parkinson's disease are related to mild cognitive dysfunction. Recently, it was shown that intracerebroventricular administration of cystatin $\mathrm{C}$ ameliorates amyotrophic lateral sclerosis-like disturbances in mice (Watanabe et al., 2018). Induction of autophagy by cystatin $C$ was suggested as a potential mechanism of prevention of cerebral vasospasm during several neurological disturbances in an animal experiment (after subarachnoid hemorrhage in mice) (Liu et al., 2013). Possible mechanism of stimulation of autophagy by cystatin $\mathrm{C}$ is suggested via the mammalian target of rapamycin (mTOR) signaling pathway (Fig. 6).

It has been found that the injections of cystatin $\mathrm{C}$ into the s. nigra of A53T mutant alpha-synuclein transgenic mice revealed neuroprotective effect in vivo in Parkinson's disease model with increased autophagy markers LC3B in different brain regions (Zou et al., 2017). Authors concluded, that neuroprotective effect of cystatin $\mathrm{C}$ in A53T transgenic mice was related to upregulating the autophagy and VEGF pathways. It presents a new approach to the treatment of Parkinson's disease through neuronal-vascular protection mediated by cystatin $\mathrm{C}$.

\section{Conclusion}

The roles of autophagy in the maintenance of cellular survival and in suppression of neurodegeneration have been evaluated in Alzheimer's, Parkinson's, and Huntington's diseases, which are accompanied by the accumulation of amyloid $\beta$, $\alpha$-synuclein, and huntingtin, respectively. Autophagy is down regulated in various ways in these diseases and decreases with ageing. Cystatin $\mathrm{C}$ is one of the potent regulators of autophagy. Changes in the expression and secretion of cystatin $\mathrm{C}$ in the brain have been shown in amyotrophic lateral sclerosis, Alzheimer's and 
Parkinson's diseases, and in some animal models of neurodegeneration, thus proving a protective function of cystatin $\mathrm{C}$. It has been suggested that cystatin $\mathrm{C}$ plays the primary role in amyloidogenesis. Controlled expression of a cystatin $\mathrm{C}$ peptide has been proposed as a new approach to therapy for Alzheimer's disease. Neuroprotective cystatin C effect in vivo (in A53T transgenic mice) was connected with upregulation in autophagy and VEGF pathways, opening a new approach to the treatment of Parkinson's disease through neuronalvascular protection mediated by cystatin $\mathrm{C}$. Administration of cystatin $\mathrm{C}$ as a regulator of autophagy holds promise as one possible approach to the treatment of neurodegenerative diseases.

\section{References}

Bjornstad P., Cherney D.Z., Maahs D.M. Update on estimation of kidney function in diabetic kidney disease. Curr. Diab. Rep. 2015;15(9):57. DOI 10.1007/s11892-015-0633-2.

Chen W.W., Cheng X., Zhang X., Zhang Q.S., Sun H.Q., Huang W.J., Xie Z.Y. The expression features of serum cystatin $\mathrm{C}$ and homocysteine of Parkinson's disease with mild cognitive dysfunction. Eur. Rev. Med. Pharmacol. Sci. 2015;19(16):2957-2963.

Chen Y., Klionsky D.J. The regulation of autophagy - unanswered questions. J. Cell Sci. 2011;124(Pt.2):161-170.

Cheung Z.H., Ip N.Y. Autophagy deregulation in neurodegenerative diseases - recent advances and future perspectives. J. Neurochem. 2011;118(3):317-325. DOI 10.1111/j.1471-4159.2011.07314.x.

Choi J.Y., Cho E.J., Lee H.S., Lee J.M., Yoon Y.H., Lee S. Tartary buckwheat improves cognition and memory function in an in vivo amyloid- $\beta$-induced Alzheimer model. Food Chem. Toxicol. 2013; 53:105-111. DOI 10.1016/j.fct.2012.11.002.

Ciechanover A., Kwon Y.T. Degradation of misfolded proteins in neurodegenerative diseases: therapeutic targets and strategies. Exp. Mol. Med. 2015:47:e147.

Coria F., Castaño E.M., Frangione B. Brain amyloid in normal aging and cerebral amyloid angiopathy is antigenically related to Alzheimer's disease beta-protein. Am. J. Pathol. 1987;129(3):422-428.

Cuervo A.M., Wong E. Chaperone-mediated autophagy: roles in disease and aging. Cell. Res. 2014;24(1):92-104.

Dehay B., Bove J., Rodriguez-Muela N., Perier C., Recasens A., Boya P., Vila M. Pathogenic lysosomal depletion in Parkinson's disease. J. Neurosci. 2010;30(37):12535-12544.

Feng Y., Yao Z., Klionsky D.J. How to control self-digestion: transcriptional, post-transcriptional, and post-translational regulation of autophagy. Trends Cell Biol. 2015;25(6):354-363. DOI 10.1016/j. tcb.2015.02.002

Galluzzi L., Baehrecke E.H., Ballabio A., Boya P., Bravo-San Pedro J.M., Cecconi F., Choi A.M., Chu C.T., Codogno P., Colombo M.I., Cuervo A.M., Debnath J., Deretic V., Dikic I., Eskelinen E.L., Fimia G.M., Fulda S., Gewirtz D.A., Green D.R., Hansen M., Harper J.W., Jäättelä M., Johansen T., Juhasz G., Kimmelman A.C., Kraft C., Ktistakis N.T., Kumar S., Levine B., LopezOtin C., Madeo F., Martens S., Martinez J., Melendez A., Mizushima N., Münz C., Murphy L.O., Penninger J.M., Piacentini M., Reggiori F., Rubinsztein D.C., Ryan K.M., Santambrogio L., Scorrano L., Simon A.K., Simon H.U., Simonsen A., Tavernarakis N., Tooze S.A., Yoshimori T., Yuan J., Yue Z., Zhong Q., Kroemer G. Molecular definitions of autophagy and related processes. EMBO J. 2017a;36(13):1811-1836. DOI 10.15252/embj.201796697.

Galluzzi L., Bravo-San Pedro J.M., Levine B., Green D.R., Kroemer G. Pharmacological modulation of autophagy: therapeutic potential and persisting obstacles. Nat. Rev. Drug Discov. 2017b;6(7):487-511. DOI 10.1038/nrd.2017.22.

Gammoh N., Fraser J., Puente C., Syred H.M., Kang H., Ozawa T., Lam D., Acosta J.C., Finch A.J., Holland E., Jiang X. Suppression of autophagy impedes glioblastoma development and induces sene- scence. Autophagy. 2016;12(9):1431-1439. DOI 10.1080/15548627. 2016.1190053.

Gao L., Jauregui C.E., Teng Y. Targeting autophagy as a strategy for drug discovery and therapeutic modulation. Future Med. Chem. 2017;9(3):335-345. DOI 10.4155/fmc-2016-0210.

Gashenko E.A., Lebedeva V.A., Brak I.V., Tsykalenko E.A., Vinokurova G.V., Korolenko T.A. Evaluation of serum procathepsin B, cystatin B and cystatin $\mathrm{C}$ as possible biomarkers of ovarian cancer. Int. J. Circumpolar Health. 2013;72:21215. DOI 10.3402/ijch. v72i0.21215

Gauthier A.C., Liu J. Neurodegeneration and neuroprotection in glaucoma. Yale J. Biol. Med. 2016;89(1):73-79.

Gauthier S., Kaur G., Mi W., Tizon B., Levy E. Protective mechanisms by cystatin $\mathrm{C}$ in neurodegenerative diseases. Front. Biosci. (Schol Ed). 2011;3:541-554.

Gomez-Santos C., Ferrer I., Santidrian A.F., Barrachina M., Gil J., Ambrosio S. Dopamine induces autophagic cell death and alpha-synuclein increase in human neuroblastoma SH-SY5Y cells. J. Neurosci. Res. 2003;73:341-350.

Ha J., Kim J. Novel pharmacological modulators of autophagy: an updated patent review (2012-2015). Expert Opin. Ther. Pat. 2016; 26(11):1273-1289.

Hara T., Nakamura K., Matsui M., Yamamoto A., Nakahara Y., Suzuki-Migishima R., Yokoyama M., Mishima K., Saito I., Okano H., Mizushima N. Suppression of basal autophagy in neural cells causes neurodegenerative disease in mice. Nature. 2006;441:885-889.

Harris H., Rubinsztein D.C. Control of autophagy as a therapy for neurodegenerative disease. Nat. Rev. Neurol. 2011;8(2):108-117. DOI 10.1038/nrneurol.2011.200.

Hu W.D., Chen J., Mao C.J., Feng P., Yang Y.P., Luo W.F., Liu C.F. Elevated cystatin $\mathrm{C}$ levels are associated with cognitive impairment and progression of Parkinson disease. Cogn. Behav. Neurol. 2016;29(3):144-149. DOI 10.1097/WNN.0000000000000100.

Huang C.K., Chang Y.T., Amstislavskaya T.G., Tikhonova M.A., Lin C.L., Hung C.S., Lai T.J., Ho Y.J. Synergistic effects of ceftriaxone and erythropoietin on neuronal and behavioral deficits in an MPTP-induced animal model of Parkinson's disease dementia. Behav. Brain Res. 2015;294:198-207. DOI 10.1016/j.bbr.2015.08.011.

Huh C.G., Håkansson K., Nathanson C.M., Thorgeirsson U.P., Jonsson N., Grubb A., Abrahamson M., Karlsson S. Decreased metastatic spread in mice homozygous for a null allele of the cystatin $\mathrm{C}$ protease inhibitor gene. Mol. Pathol. 1999;52(6):332-340.

Hwang H.Y., Cho S.M., Kwon H.J. Approaches for discovering novel bioactive small molecules targeting autophagy. Expert Opin. Drug Discov. 2017;12(9):909-923. DOI 10.1080/17460441.2017.1349751.

Johnston T.P., Korolenko T.A., Bgatova N.P. Statins and Yeast Polysaccharides in the Treatment of Hyperlipidemia and Liver Steatosis, Role of Autophagy. In: Berhardt L.V. (Ed.). Advances in Medicine and Biology. Vol. 110. New York: Nova Science Publ., 2017;31-60.

Kaminskyy V., Zhivotovsky B. Proteases in autophagy. Biochim. Biophys. Acta. 2012;1824(1):44-50.

Kaur G., Levy E. Cystatin C in Alzheimer's disease. Front. Mol. Neurosci. 2012;6(5):79. DOI 10.3389/fnmol.2012.00079.

Keppler D. Towards novel anti-cancer strategies based on cystatin function. Cancer Lett. 2006;235(2):159-176.

Kiriyama Y., Nochi H. The function of autophagy in neurodegenerative diseases. Int. J. Mol. Sci. 2015;16(11):26797-26812. DOI 10.3390/ ijms161125990.

Korolenko T.A., Cherkanova M.S., Gashenko E.A., Johnston T.P., Bravve I.Yu. Cystatin C, Atherosclerosis and Lipid-Lowering Therapy by Statins. In: Cohen J.B., Ryseck L.P. (Eds.). Cystatins, Protease Inhibitors, Biomarkers and Immunomodulators. Nova Science Publ., USA, 2011;187-204.

Korolenko T.A., Pisareva E.E., Filyushina E.E., Johnston T.P., Machova E. Serum cystatin C and chitotriosidase in acute P-407 induced dyslipidemia: can they serve as potential early biomarkers for atherosclerosis? Exp. Toxicol. Pathol. 2015;67(9):459-466. DOI 10.1016/j.etp.2015.06.003. 
Korolenko T.A., Tuzikov F.V., Cherkanova M.S., Johnston T.P., Tuzikova N.A., Loginova V.M., Filjushina E.E., Kaledin V.I. Influence of atorvastatin and carboxymethylated glucan on the serum lipoprotein profile and MMP activity of mice with lipemia induced by poloxamer 407. Can. J. Physiol. Pharmacol. 2012;90(2):141-153. DOI $10.1139 / \mathrm{y} 11-118$.

Kovács T., Billes V., Komlós M., Hotzi B., Manzéger A., Tarnóci A., Papp D., Szikszai F., Szinyákovics J., Rácz Á., Noszál B., Veszelka S., Walter F.R., Deli M.A., Hackler L., Jr, Alfoldi R., Huzian O., Puskas L.G., Liliom H., Tárnok K., Schlett K., Borsy A., Welker E., Kovács A.L., Pádár Z., Erdős A., Legradi A., Bjelik A., Gulya K., Gulyás B., Vellai T. The small molecule AUTEN-99 (autophagy enhancer-99) prevents the progression of neurodegenerative symptoms. Sci. Rep. 2017;7:42014. DOI 10.1038/srep42014.

Lee D.C., Womble T.A., Mason C.W., Jackson I.M., Lamango N.S., Severs W.B., Palm D.E. 6-Hydroxydopamine induces cystatin $\mathrm{C}$-mediated cysteine protease suppression and cathepsin D activation. Neurochem. Int. 2007;50(4):607-618.

Lee J.A. Autophagy in neurodegeneration: two sides of the same coin. BMB Rep. 2009;42(6):324-330.

Li W., Sultana N., Siraj N., Ward L.J., Pawlik M., Levy E., Jovinge S., Bengtsson E., Yuan X.-M. Autophagy dysfunction and regulatory cystatin $\mathrm{C}$ in macrophage death of atherosclerosis. J. Cell. Mol. Med. 2016;20(9):1664-1672.

Ling D., Salvaterra P.M. A central role for autophagy in Alzheimer-type neurodegeneration. Autophagy. 2009;5(5):738-740.

Liu Y., Cai H., Wang Z., Li J., Wang K., Yu Z., Chen G. Induction of autophagy by cystatin $\mathrm{C}$ : a potential mechanism for prevention of cerebral vasospasm after experimental subarachnoid hemorrhage. Eur. J. Med. Res. 2013;18:21. DOI 10.1186/2047-783X-18-21.

Luo J. Autophagy and ethanol neurotoxicity. Autophagy. 2014;10(12): 2099-2108. DOI 10.4161/15548627.2014.981916.

Maetzler W., Schmid B., Synofzik M., Schulte C., Riester K., Huber H., Brockmann K., Gasser T., Berg D., Melms A. The CST3 BB genotype and low cystatin $\mathrm{C}$ cerebrospinal fluid levels are associated with dementia in Lewy body disease. J. Alzheimers Dis. 2010;19(3):937942. DOI 10.3233/JAD-2010-1289.

Malagelada C., Jin Z.H., Jackson-Lewis V., Przedborski S., Greene L.A. Rapamycin protects against neuron death in in vitro and in vivo models of Parkinson's disease. J. Neurosci. 2010;30(3):1166-1175. DOI 10.1523/JNEUROSCI.3944-09.2010.

Martini-Stoica H., Xu Y., Ballabio A., Zheng H. The autophagy-lysosomal pathway in neurodegeneration: a TFEB perspective. Trends Neurosci. 2016;39(4):221-234. DOI 10.1016/j.tins.2016.02.002.

Mathews P.M., Levy E. Cystatin C in aging and in Alzheimer's disease. Ageing Res. Rev. 2016;32:38-50. DOI 10.1016/j.arr.2016.06.003.

Maxfield F. Role of endosomes and lysosomes in human disease. Cold Spring Harb. Perspect. Biol. 2014;6(5):a016931. DOI 10.1101/ cshperspect.a016931.

Mi W., Pawlik M., Sastre M., Jung S.S., Radvinsky D.S., Klein A.M., Sommer J., Schmidt S.D., Nixon R.A., Mathews P.M., Levy E. Cystatin $\mathrm{C}$ inhibits amyloid-beta deposition in Alzheimer's disease mouse models. Nat. Genet. 2007;39(12):1440-1442.

Nalivaeva N.N., Turner A.J. Role of ageing and oxidative stress in regulation of amyloid-degrading enzymes and development of neurodegeneration. Curr. Aging Sci. 2017;10(1):32-40.

Park S.H., Kim J.H., Bae S.S., Hong K.W., Lee D.S., Leem J.Y., Choi B.T., Shin H.K. Protective effect of the phosphodiesterase III inhibitor cilostazol on amyloid $\beta$-induced cognitive deficits associated with decreased amyloid $\beta$ accumulation. Biochem. Biophys. Res. Commun. 2011;408(4):602-608. DOI 10.1016/j.bbrc.2011.04.068.

Poteryaeva O.N., Falameyeva O.V., Korolenko T.A., Kaledin V.I., Djanayeva S.J., Nowicky J.W., Sandula J. Cysteine proteinase inhibitor level in tumor and normal tissues in control and cured mice. Drugs Exp. Clin. Res. 2000;26(5-6):301-306.

Přikrylová Vranová H., Mareš J., Nevrlý M., Stejskal D., Zapletalová J., Hluštík P., Kaňovský P. CSF markers of neurodegeneration in Par- kinson's disease. J. Neural Transm. (Vienna). 2010;117(10):11771181. DOI 10.1007/s00702-010-0462-z.

Pupyshev A.B., Gutina E.M., Fedina R.G., Michurina S.V., Shurlygina A.V., Verbitskaya L.V. Effect of benz(a)pyrene and constant light exposure on rat liver lysosomes and biliary excretion of lysosomal enzymes. Bull. Exp. Biol. Med. 2005;139(1):34-37.

Pupyshev A.B., Korolenko T.A., Akopyan A.A., Amstislavskaya T.G., Tikhonova M.A. Suppression of autophagy in the brain of transgenic mice with overexpression of A53T-mutant $\alpha$-synuclein as an early event at synucleinopathy progression. Neurosci. Lett. 2018;672:140144. DOI 10.1016/j.neulet.2017.12.001.

Son J.H., Shim J.H., Kim K.-H., Ha J.-Y., Han J.Y. Neuronal autophagy and neurodegenerative diseases. Exp. Molec. Med. 2012;44(2): 89-98.

Stoka V., Turk B., Turk V. Lysosomal cysteine proteases: structural features and their role in apoptosis. IUBMB Life. 2005;57(4-5): 347-353

Sundelöf J., Arnlöv J., Ingelsson E., Sundström J., Basu S., Zethelius B., Larsson A., Irizarry M.C., Giedraitis V., Rönnemaa E., Degerman-Gunnarsson M., Hyman B.T., Basun H., Kilander L., Lannfelt L. Serum cystatin C and the risk of Alzheimer disease in elderly men. Neurology. 2008;71(14):1072-1079. DOI 10.1212/01. wnl.0000326894.40353.93.

Svechnikova I.G., Korolenko T.A., Stashko Ju.F., Kaledin V.I., Nikolin V.P., Nowicky J.W. The influence of Ukrain on the growth of HA-1 tumor in mice: the role of cysteine proteinases as markers of tumor malignancy. Drugs Exp. Clin. Res. 1998;24(5-6):261-269.

Tikhonova M.A., Ho S.C., Akopyan A.A., Kolosova N.G., Weng J.C., Meng W.Y., Lin C.L., Amstislavskaya T.G., Ho Y.J. Neuroprotective effects of ceftriaxone treatment on cognitive and neuronal deficits in a rat model of accelerated senescence. Behav. Brain Res. 2017; 330:8-16. DOI 10.1016/j.bbr.2017.05.002.

Tizon B., Ribe E.M., Mi W., Troy C.M., Levy E. Cystatin C protects neuronal cells from amyloid-beta-induced toxicity. J. Alzheimers Dis. 2010a;19(3):885-894. DOI 10.3233/JAD-2010-1291.

Tizon B., Sahoo S., Yu H., Gauthier S., Kumar A.R., Mohan P., Figliola M., Pawlik M., Grubb A., Uchiyama Y., Bandyopadhyay U., Cuervo A.M., Nixon R.A., Levy E. Induction of autophagy by cystatin $\mathrm{C}$ : a mechanism that protects murine primary cortical neurons and neuronal cell lines. PLoS One. 2010b;5(3):e9819. DOI 10.1371/ journal.pone.0009819.

Torra A., Parent A., Cuadros T., Rodríguez-Galván B., Ruiz-Bronchal E., Ballabio A., Bortolozzi A., Vila M., Bové J. Overexpression of TFEB drives a pleiotropic neurotrophic effect and prevents Parkinson's disease-related neurodegeneration. Mol. Ther. 2018;26(6): 1552-1567. DOI 10.1016/j.ymthe.2018.02.022.

Viscomi M.T., D'Amelio M. The "Janus-faced role" of autophagy in neuronal sickness: focus on neurodegeneration. Mol. Neurobiol. 2012;46(2):513-521. DOI 10.1007/s12035-012-8296-3.

Wang D., Hiesinger P.R. Autophagy, neuron-specific degradation and neurodegeneration. Autophagy. 2012;8(4):711-713. DOI 10.4161/ auto. 19660 .

Wang R., Chen Z., Fu Y., Wei X., Liao J., Liu X., He B., Xu Y., Zou J., Yang X., Weng R., Tan S., McElroy C., Jin K., Wang Q. Plasma cystatin $\mathrm{C}$ and high-density lipoprotein are important biomarkers of Alzheimer's disease and vascular dementia: a cross-sectional study. Front. Aging Neurosci. 2017;9:26. DOI 10.3389/fnagi.2017.00026.

Watanabe S., Komine O., Endo F., Wakasugi K., Yamanaka K. Intracerebroventricular administration of Cystatin $\mathrm{C}$ ameliorates disease in SOD1-linked amyotrophic lateral sclerosis mice. J. Neurochem. 2018;145(1):80-89. DOI 10.1111/jnc. 14285 .

Weng J.C., Tikhonova M.A., Chen J.H., Shen M.S., Meng W.Y., Chang Y.T., Chen K.H., Liang K.C., Hung C.S., Amstislavskaya T.G., Ho Y.J. Ceftriaxone prevents the neurodegeneration and decreased neurogenesis seen in a Parkinson's disease rat model: an immunohistochemical and MRI study. Behav. Brain Res. 2016;305: 126-139. DOI 10.1016/j.bbr.2016.02.034. 
Wu C.F., Yang J.Y., Wang F., Wang X.-X. Resveratrol: botanical origin, pharmacological activity and applications. Chin. J. Nat. Med. 2013; 11(1):1-15.

Xiong K.P., Dai Y.P., Chen J., Xu J.M., Wang Y., Feng P., You S.J., Liu C.F. Increased serum cystatin C in early Parkinson's disease with objective sleep disturbances. Chin. Med. J. (Engl). 2018;131(8):907911. DOI 10.4103/0366-6999.229902.

Xu L., Sheng J., Tang Z., Wu X., Yu Y., Guo H., Shen Y., Zhou C., Paraoan L., Zhou J. Cystatin C prevents degeneration of rat nigral dopaminergic neurons: in vitro and in vivo studies. Neurobiol. Dis. 2005; 18:152-165.

Xu Y., Ding Y., Li X., Wu X. Cystatin C is a disease-associated protein subject to multiple regulation. Immunol. Cell Biol. 2015;93(5):442451. DOI 10.1038/icb.2014.121.

Xu Y., Schnorrer P., Proietto A., Kowalski G., Febbraio M.A., AchaOrbea H., Dickins R.A., Villadangos J.A. IL-10 controls cystatin C synthesis and blood concentration in response to inflammation through regulation of IFN regulatory factor 8 expression. J. Immunol. 2011;186(6):3666-3673. DOI 10.4049/jimmunol.1001934.

Yamamoto-Watanabe Y., Watanabe M., Jackson M., Akimoto H., Sugimoto K., Yasujima M., Wakasaya Y., Matsubara E., Kawara- bayashi T., Harigaya Y., Lyndon A.R., Shoji M. Quantification of cystatin $\mathrm{C}$ in cerebrospinal fluid from various neurological disorders and correlation with G73A polymorphism in CST3. Brain Res. 2010;1361:140-145. DOI 10.1016/j.brainres.2010.09.033.

Zerovnik E. The emerging role of cystatins in Alzheimer's disease. Bioessays. 2009;31(6):597-599. DOI 10.1002/bies.200900012.

Zhai J.L., Ge N., Zhen Y., Zhao Q., Liu C. Corticosteroids significantly increase serum cystatin $\mathrm{C}$ concentration without affecting renal function in symptomatic heart failure. Clin. Lab. 2016;62(1-2):203-207.

Zhong X.M., Hou L., Luo X.N., Shi H.S., Hu G.Y., He H.B., Chen X.R., Zheng D., Zhang Y.F., Tan Y., Liu X.J., Mu N., Chen J.P., Ning Y.P. Alterations of CSF cystatin $\mathrm{C}$ levels and their correlations with CSF $\mathrm{A} \beta 40$ and $\mathrm{A} \beta 42$ levels in patients with Alzheimer's disease, dementia with Lewy bodies and the atrophic form of general paresis. PLoS One. 2013;8(1):e55328. DOI 10.1371/journal.pone.0055328.

Zou J., Chen Z., Wei X., Chen Z., Fu Y., Yang X., Chen D., Wang R., Jenner P., Lu J.H., Li M., Zhang Z., Tang B., Jin K., Wang Q. Cystatin $\mathrm{C}$ as a potential therapeutic mediator against Parkinson's disease via VEGF-induced angiogenesis and enhanced neuronal autophagy in neurovascular units. Cell Death Dis. 2017;8(6):e2854. DOI 10.1038/cddis.2017.240.

ORCID ID

E.L. Zavjalov orcid.org/0000-0002-9412-3874

Acknowledgements. This work was supported partially by grant No. 16-04-01423-a from the Russian Foundation for Basic Research (Russia), to T.A.K. budget from the project No. 0538-2014-0009 of the Scientific Research Institute of Physiology and Basic Medicine (SRIPhBM) and a unique scientific resource "Biological collection - Genetic biomodels of neuro-psychiatric disorders" (No. 493387) at the SRIPhBM. The studies were implemented using the equipment of the Center for Genetic Resources of Laboratory Animals at ICG SB RAS, supported by the Ministry of Education and Science of Russia (unique identifier of the project: RFMEFI62117X0015). The English language was corrected and certified bu shevchuk-editing.com.

Conflict of interest. The authors declare no conflict of interest.

Received September 24, 2018. Revised February 11, 2019. Accepted February 11, 2019. 